[Agr. Biol. Chem., Vol. 25, No. 5, p. 362 366, 1961]

\title{
Hydroxyproline in Chlorella and its Metabolism in Tobacco Leaves*
}

\author{
By Koichi Shimbayashi ** \\ Department of Biochemistry, University of Wisconsin, Madison 6, Wisconsin, U.S.A.
}

Received December 14, 1960

\begin{abstract}
Hydroxyproline and other compounds were labeled with $\mathrm{C}^{14}$ by Chlorella pyrenoidosa supplied with $\mathrm{C}^{14} \mathrm{O}_{2}$ in the light. The hydroxyproline recovered from a hydrolysate of the algae was administered through the cut bases of tobacco leaves. The leaves formed little proline from the hydroxyproline, but the $\mathbf{C}^{14}$ label was transferred to a variety of other amino acids. Although hydroxyproline is not abundant in plants, it appears to be an active metabolite.
\end{abstract}

There have been numerous studies on the incorporation of $\mathrm{C}^{14}$-labeled amino acids into plant proteins in recent years. Most of the studies have employed easily metabolizable amino acids, but recently Dougall and Shimbayashi ${ }^{1}$ ) have followed the incorporation of tyrosine, uniformly labeled with $\mathrm{C}^{14}$, into tobacco callus tissue cultures; it was shown that tyrosine is not converted to any other amino acid but is incorporated directly into tobacco tissue protein.

In the experiments with tobacco tissue cultures, the "cell wall residue". fraction had a considerable amount of hydroxyproline, but there was no hydroxyproline in any other fractions, such as the "soluble amino acids", "soluble protein" and "formic acid soluble cell wall material". This localization of hydroxyproline in a specific fraction suggested the present investigation of the metabolism of hydroxyproline in whole tobacco leaves in the dark for extended periods. In addition, the experiments gave some indication of the

* Published with the approval of the Director of the Wisconsin Agricultural Experiment Station.

** Recipient of a Rockefeller Foundation Fellowship. Present address : National Institute of An imal Health, Kodaira-machi, Kitatamagun, Tokyo, Japan.

1) D.K. Dougall and K. Shimbayashi, Plant Physiol., 35, 396 (1960). occurrence of hydroxyproline in plant proteins.

\section{MATERIALS AND METHODS}

\section{Preparation of Labeled Amino Acids.}

For preparation of amino acids uniformly labeled with $\mathrm{C}^{14}$, Chlorella pyrenoidosa was grown in a medium (McBride, L., private communication) containing per liter: $\mathrm{NH}_{4} \mathrm{NO}_{3}, 2.0 \mathrm{~g} ; \mathrm{MgSO}_{4} \cdot 7 \mathrm{H}_{2} \mathrm{O}, 0.308 \mathrm{~g} ; \mathrm{KH}_{2} \mathrm{PO}_{4}$, $1.96 \mathrm{~g} ; \mathrm{K}_{2} \mathrm{HPO}_{4}, 3.43 \mathrm{~g} ; \mathrm{CaCl}_{2} \cdot 2 \mathrm{H}_{2} \mathrm{O}, 0.073 \mathrm{~g}$; and $\mathrm{KHCO}_{3}, 1.25 \mathrm{~g}$. Iron chelated by ethylenediamine tetraacetic acid was provided in the ferric form at $5 \mathrm{ppm}$, and the micro elements were supplied by $0.5 \mathrm{ml}$ per liter of Hoagland and Arnon Solution ${A_{5}}^{2}{ }^{2}$ diluted $1 / 25$ from the strength recommended for higher plants. The phosphates were adjusted to $\mathrm{pH} 6.2$, and the remaining nutrients without potassium bicarbonate were autoclaved separately at $120^{\circ} \mathrm{C}$ for 30 minutes. The potassium bicarbonate was saturated with carbon dioxide, filtered through a fritted glass bacterial filter, and added aseptically to the medium.

The algae were grown in four liters of medium containing 2.5 millicuries $\mathrm{C}^{14}$ per liter as potassium bicarbonate. The cultures were stirred magnetically, cooled by a fan, and illuminated by fluoroescent lamps. The growth was allowed to continue to maximum population density, and then the algae were collected by centrifugation, washed once with water, and heated to boiling in $75 \%$ ethanol. The residue was recovered,

2) D.I. Arnon, Am. J. Botany, 25, 322 (1938). 
washed, hydrolyzed with $6 \mathrm{~N}$ hydrochloric acid under reflux for 24 hours, and excess acid was removed by vacuum distillation.

The slightly modified Hirs, Moore, and Stein ${ }^{3)}$ method employing acetic and hydrochloric acids for elution was used to separate the amino acids. To scparate tyrosine, glutamic acid and aspartic acid, Dowex 1 X10 (200 400 mesh) was used in its acetate form at room temperature in a column $40 \times 2 \mathrm{~cm}$. The concentration of the eluant was increased gradually by feeding $1 \mathrm{~N}$ acetic acid into a $250 \mathrm{ml}$ mixing chamber containing $0.1 \mathrm{~N}$ acetic acid. The flow rate was $8 \mathrm{ml}$ per hour. The first fraction from the Dowex 1 column, containing various basic and neutral amino acids, was separated on a $2.5 \times 150 \mathrm{~cm}$ column of Dowex $50 \mathrm{X} 4$ $\left(\mathrm{H}^{+}\right)$at room temperature. The concentration of hydrochloric acid was increased gradually after the emergence of glycine, and 5 to 6 four $\mathrm{ml}$ fractions of the effluent were collected per hour. The recovery of amino acids appeared to be low with the Dowex 50 column and hydrochloric acid as eluting agent in a preliminary experiment, but the apparent recovery was improved later by strengthening the buffering of the ninhydrin solution to maintain an optimal pH. Each group of effluent fractions corresponding to a peak was pooled and concentrated to dryness, dissolved in a small amount of distilled water, and a sample of the concentrate was developed on a paper chromatogram. The chromatograms were radioautographed to identify each radioactive fraction. The fractions 349 to 367 , corresponding to the region of ammonia (and hydroxyproline), were pooled and freed of hydrochloric acid in a rotary evaporator followed by two passages through Dowex 1 X10 with $0.5 \mathrm{~N}$ acetic acid as eluting agent.

The concentrated amino acid solution recovered from fractions 349 to 367 gave little violet color with ninhydrin. An aliquot of the solution was analyzed by paper chromatography and radioautography, and another aliquot was added to a standard amino acid mixture containing $1 \mu$ mole of most amino acids and $5 \mu$ moles of hydroxyproline. The mixture was separated $^{4)}$ with Dowex $50 \times 8$ at $30^{\circ} \mathrm{C}$ and the unknown amino acid mixture proved to be mainly hydroxyproline together with some glutamic acid and glycine.

The amino acid solution used for the tobacco leaf

3) C.H.W. Hirs, S. Moore and W.H. Stein, J. Am. Chem. Soc., 76, 6063 (1954).

4) S. Moore, D.H. Spackman and W.H. Stein, Anal. Chem., 30, experiments had the following $\mathrm{C}^{14}$ distribution upon passage through the Dowex 50 column: $74.0 \%$ of the total $\mathrm{C}^{14}$ added to the column was recovered as hydroxyproline, $3.2 \%$ as glutamic acid, $6.0 \%$ as glycine, and $7.6 \%$ as an unknown compound $(91 \%$ total recovery). The 75,000 c.p.m. added to each tobacco leaf thus contained approximately 55,500 c.p.m. as hydroxyproline, 2,400 c.p.m. as glutamic acid, 4,500 c.p.m. as glycine, and 5,700 c.p.m. as an unknown compound.

\section{Administration of $\mathrm{C}^{14}$-Hydroxyproline to Tobacco Leaves and Analysis.}

Young leaves weighing about $5 \mathrm{~g}$ were picked at about 9:00 a.m. from tobacco plants (Nicotiana tabacum var. Wisconsin Havana 38), and the cut leaf bases were immediately recut under water. The cut base of each of three leaves was immersed in $1 \mathrm{ml}$ of $\mathrm{C}^{14}$. hydroxyproline solution in a small beaker; each $\mathrm{ml}$ of the amino acid solution gave 75,000 c.p.m. with a thin window Geiger counter as indicated earlier. The leaves were kept in a dark room for 1.5 hours, 3 hours, and 10 hours after the treatment was started, and during the experiment small amounts of water were added to the beakers as needed. To stimulate transpiration, air was blown across the leaves with a fan. After each experimental period, a leaf was ground in a small amount of $6 \mathrm{~N}$ hydrochloric acid with mortar and pestle, and then was transferred into a $500 \mathrm{ml}$ round bottom flask with $50 \mathrm{ml}$ of $6 \mathrm{~N}$ hydrochloric acid. After refluxing for 24 hours, the hydrolysate was filtered to remove humin, transferred into another round bottom flask, connected to a rotating vacuum evaporator and the hydrochloric acid was removed at $50 \sim 60^{\circ} \mathrm{C}$. Water was added and evaporated twice, and each of the final residues was dissolved in $10 \mathrm{ml}$ of water.

The acidic and neutral amino acids from $1 \mathrm{ml}$ of hydrolysate were separated ${ }^{4)}$ on Dowex $50 \times 8$ (200 400 mesh, sodium form) in a $150 \times 0.9 \mathrm{~cm}$ column operated at $50^{\circ} \mathrm{C}$ with $0.2 \mathrm{~N}$ sodium citrate buffer plus redistilled thiodiglycol, $\mathrm{pH} 3.25$, as eluant until alanine was displaced (about 160 fractions); then the buffer and temperature were changed to $0.2 \mathrm{~N}$ sodium citrate buffer plus redistilled thiodiglycol, $\mathrm{pH} 4.25$, and $60^{\circ} \mathrm{C}$. The effluents were collected in $2 \mathrm{ml}$ fractions at a rate of $12 \mathrm{ml}$ per hour; the flow rate was regulated by a proportioning pump. To separate aspartic acid and hydroxyproline properly, another column was operated at $30^{\circ} \mathbf{C}$. 
The basic amino acids were separated with Amberlite 120 , type 3 , in a $15 \times 0.9 \mathrm{~cm}$ column operated at $50^{\circ} \mathrm{C}$ with $0.35 \mathrm{~N}$ sodium citrate buffer, $\mathrm{pH}$ 5.28; $1 \mathrm{ml}$ of hydrolysate was added to the column, and $2 \mathrm{ml}$ fractions were collected at a rate of $12 \mathrm{ml}$ per hour. The Amberlite resin was fractionated into various particle sizes by a hydraulic method ${ }^{5)}$, and the fraction of mean particle size 32 microns was used (Table I).

TABLE I. Recovery OF Amino AciDs ON A DOWEX 50 Column From A Mixture Containing ONE MICROMOLE OF EACH AMINO ACID

\begin{tabular}{|c|c|c|c|c|c|}
\hline Amino acid & $\begin{array}{l}\text { Micromo } \\
\text { leucine }\end{array}$ & $\begin{array}{l}\text { bles rec } \\
\text { color st }\end{array}$ & $\begin{array}{l}\text { overed, } \\
\text { andard }\end{array}$ & Average & $\begin{array}{l}\text { Color yiel } \\
\text { factor }\end{array}$ \\
\hline Lysine & 1.05, & 1.06, & 1.11 & 1.07 & 0.935 \\
\hline Histidine & 1.06, & 0.94 , & & & 1.00 \\
\hline Ammonia & 1.06, & 1.06, & & & 917 \\
\hline Argin & 0.97, & 1.02 , & & 1.01 & \\
\hline Aspartic acid & 0.95 & 0.91 , & & & 75 \\
\hline Threonine & 0.92 & 0.91 , & & 0.915 & 1.093 \\
\hline Serine & & 0.93 , & 0.92 & 0.93 & 1.075 \\
\hline mic acid & 0.93 & & 0.91 & 0 . & 1.087 \\
\hline Proline & 0.19 & 0.21 , & & 21 & 4.762 \\
\hline & & 0.96 & 0.90 & 0.93 & 1.075 \\
\hline Alani & 0.97 & 0.93 & & & 1.031 \\
\hline Cystine & & 0.52 , & 0.46 & 0.50 & 2.000 \\
\hline Vali & 0.93, & 0.99 , & 0.89 & & 1.064 \\
\hline Methionine & & 0.95 & 0.89 & 0.92 & 1.087 \\
\hline$i$-Leucine & 1.01 & 0.95 & 0.96 & 0.97 & 1.031 \\
\hline Leucine & & 1.00 & 0.97 & 0.99 & 1.010 \\
\hline Tyrosine & 0.98 & 0.95 & 1.03 & 0.99 & 1.010 \\
\hline Phenylalan & 0.92 , & 0.93 , & 0.93 & 0.93 & 1.075 \\
\hline$\beta$-Alanine & 0.40 & 0.44 & & 0.42 & 2.381 \\
\hline
\end{tabular}

Hydroxyproline $0.433,0.424 \mu$ moles recovered (leucine standard), $5.00 \mu$ moles added

11.50

The ninhydrin method of Moore and Stein ${ }^{6)}$ was employed; the reagent was stored under $\mathrm{N}_{2}$ and consisted of $10 \mathrm{~g}$ ninhydrin, $1.5 \mathrm{~g}$ hydrindantin, $375 \mathrm{ml}$ methyl cellosolve freed of peroxide and $125 \mathrm{ml} \mathrm{pH}$ 5.5, $4 \mathrm{~N}$ acetate buffer.

A one $\mathrm{ml}$ aliquot of each effluent fraction from each amino acid peak was mixed with $0.5 \mathrm{ml}$ of $2 \%$ gelatin solution in $0.3 \mathrm{~N}$ sodium hydroxide, and then $1 \mathrm{ml}$ of the mixture was plated on a 1 inch diameter flat copper planchet. The planchets were dried over night at room temperature and were counted with a thin window Geiger counter.

5) P.B. Hamilton, Anal. Chem., 30, 914 (1958).

6) S. Moore and W.H. Stein, J. Biol. Chem., 211, 907 (1954).

\section{RESULTS AND DISCUSSION}

\section{Hydroxyproline in Chlorella pyrenoidosa.}

The use of Chlorella pyrenoidosa for the biological preparation of $\mathrm{C}^{14}$-labeled compounds has been rather widely adopted, because the organism utilizes $\mathbf{C}^{\mathbf{1 4}}$ efficiently, and can be grown conveniently on a large scale ${ }^{\text {r) }}$. Although hydroxyproline has been found in a few plants ${ }^{8 \sim 11}$ it has not been reported in earlier analyses of Chlorella pyrenoidosa ${ }^{7,11)}$; it was clearly present, though not abundant, in the hydrolysate we recovered from the organism. Its low concentration and low color yield with ninhydrin probably account for the fact that others have overlooked it. The procedure used in our experiments for this separation of amino acids involved only slight modifications

Table II. Amino ACID Content of Hydrolysate of Chlorella pyrenoidosa

$\begin{array}{lrc}\text { Amino acid } & \begin{array}{c}\text { recovered } \\ \text { from } \\ \text { column }\end{array} & \begin{array}{c}\text { composition calculated } \\ \text { from recovered } \\ \text { amino acids }\end{array} \\ \text { Aspartic acid } & 276.5 & 9.34 \\ \text { Glutamic acid } & 256.6 & 8.67 \\ \text { Tyrosine } & 74.0 & 2.50 \\ \text { Serine } & 77.8 & 2.63 \\ \text { Threonine } & 78.0 & 2.64 \\ \text { Glycine } & 226.6 & 7.69 \\ \text { Ammonia } & 520.2 & 17.58 \\ \text { Alanine } & 327.5 & 11.08 \\ \text { Valine } & 156.6 & 5.30 \\ \text { Proline } & 183.2 & 6.20 \\ \text { Methionine } & 39.8 & 1.35 \\ i \text {-Leucine } & 90.7 & 3.06 \\ \text { Leucine } & 234.9 & 7.95 \\ \text { Cystine } & 2.5 & 0.08 \\ \text { Lysine } & 142.4 & 4.82 \\ \text { Histidine } & 32.0 & 1.08 \\ \text { Arginine } & 123.6 & 4.18 \\ \text { Phenylalanine } & 113.7 & 3.85\end{array}$

7) L. Schieler, L.E. McClure and M.S. Dunn, J. Biol. Chem., 203, 1039 (1953)

8) G. Leaf, I.C. Gardner and G. Bond, Biochem. J., 72, 662 (1959), 9) F.C. Steward, J.F. Thompson and J.K. Pollard, J. Exptl. Botany. 9, 1 (1958).

10) F.C. Steward and J.K. Pollard, Nature, 182, 828 (1958).

11) L. Schieler, L.E. McClure and M.S. Dunn, Food Research, 18, 377 (1953). 
of the method of Hirs, et al.3). In their experiments with a hydrolysate of human serum albumin no hydroxyproline appeared, so others following the method may not have looked specifically for hydroxyproline. Hydroxyproline appears to be much less abundant than proline in living materials; although low in concentration, hydroxyproline may be widespread in higher plants.

Table II indicates the mole percentage composition of the amino acids in an acid hydrolysate of Chlorella pyrenoidosa. Alanine, aspartic acid, glutamic acid, leucine and glycine were particularly abundant, and proline, valine, lysine, arginine and phenylalanine also were present in high concentrations. Cystine, histidine and methionine were least abundant.

\section{Amino Acid Composition of the Hydrolysates of Tobacco Leaves.}

Table III indicates the reasonably constant amino acid composition of tobacco leaves after

Table III. Amino Acid Content of HydrolySATES OF TOBACCO LEAVES

\begin{tabular}{|c|c|c|c|}
\hline \multirow{2}{*}{ Amino acid } & \multicolumn{3}{|c|}{$\begin{array}{l}\text { Period of exposure to } \\
\mathrm{C}^{14} \text {-hydroxyproline }\end{array}$} \\
\hline & $\begin{array}{l}1.5 \mathrm{hr} ., \\
\text { mole } \%\end{array}$ & $\begin{array}{l}3.0 \mathrm{hr} ., \\
\text { mole } \%\end{array}$ & $\begin{array}{l}10 \mathrm{hr} ., \\
\text { mole } \%\end{array}$ \\
\hline Aspartic acid & 6.86 & 7.35 & 8.21 \\
\hline Threonine & 3.38 & 3.35 & 4.21 \\
\hline Serine & 3.36 & 3.35 & 5.00 \\
\hline Glutamic acid & 11.53 & 11.21 & 12.19 \\
\hline Proline & 6.55 & 4.86 & 7.76 \\
\hline Glycine & 8.15 & 7.80 & 7.82 \\
\hline Valine & 5.70 & 6.05 & 5.55 \\
\hline Methionine & 1.29 & 1.36 & 1.26 \\
\hline iso-Leucine & 3.82 & 4.43 & 3.65 \\
\hline Leucine & 6.56 & 7.99 & 6.51 \\
\hline Tyrosine & 1.88 & 1.82 & 1.88 \\
\hline Phenylalanine & 2.77 & 3.27 & 3.04 \\
\hline Lysine & 5.36 & 5.79 & 4.73 \\
\hline Histidine & 1.34 & 1.42 & 1.31 \\
\hline Ammonia & 18.80 & 17.04 & 16.70 \\
\hline Arginine & 3.40 & 3.71 & 3.25 \\
\hline Cysteic acid & 0.19 & 0.88 & 0.84 \\
\hline Total & 99.29 & 99.67 & 101.00 \\
\hline
\end{tabular}

3 periods of exposure to $\mathrm{C}^{14}$-hydroxyproline. Aspartic acid, threonine, serine, phenylalanine, cysteic acid and proline showed the only marked increases with time. The concentration of ammonia decreased gradually, as did that of a few of the amino acids. Because of its extremely faint color with ninhydrin, hydroxyproline was not prominent but was demonstrable in the effluent from the column operated at $30^{\circ} \mathrm{C}$. Cystine was not detected in any experiment. Fractions $45 \sim 55$ yielded a red color with ninhydrin; this unknown compound (s) appearing before aspartic acid had slight radioactivity.

\section{Metabolism of Hydroxyproline.}

About $50 \%$ of the hydroxyproline added (55,500 c.p.m. initially) to tobacco leaves was metabolized within 1.5 hours, and about $80 \%$ within 3 hours (Table IV). The radioactivity of threonine and glutamic acid (2,400 c.p.m. initially present in solution as a contaminant) decreased with time, and a slower decrease was noted for glycine, valine and the unknown compound. Contrary to this, the radioactivity of proline increased actively. Accumulation of $\mathrm{C}^{14}$ during the first 1.5 hours was particularly marked into threonine. It is quite possible that the $\mathrm{C}^{14}$ in threonine could have arisen chiefly from labeled glycine and glutamic acid which contaminated the solution of hydroxyproline.

The metabolism of hydroxyproline in higher plants has not been studied thoroughly, probably because hydroxyproline often escapes notice as a result of its low color yield with ninhydrin, and because of the general belief that it is not a significant metabolite in plants. However, hydroxyproline was demonstrated in tobacco leaves by Kunitake et al.12). The leaves they exposed to $\mathrm{C}^{14} \mathrm{O}_{2}$ in the dark for 15 minutes incorporated $\mathrm{C}^{14}$ into hydroxyproline; although the level of $\mathbf{C}^{14}$ in hydroxy-

12) G. Kunitake, C. Stitt and P. Saltman, Plant Physiol., 34, 123
(1959). 
TABle IV. Gis IN Amino Acids of Tobacco Leaves AFter Exposure to $\mathrm{C}^{14}$-HYDROXYPROLINE FOR $1.5,3$ AND 10 HOURS

Amino acid

Hydroxyproline

Threonine

Glutamic acid

Proline

Glycine

Valine

Leucine

Unknown compd.*

* The unknown compound gave a red color with ninhydrin.

proline was low, it was comparable to that of many other amino acids in the leaves.

The present experiment suggested that hydroxyproline was relatively rapidly metabolized in the dark. Much of the radioactivity which was added to the tobacco leaves remained in the leaf hydrolysate, even after 10 hours exposure to labeled hydroxyproline. The incorporation of $\mathrm{C}^{\mathbf{1 4}}$ into other amino acids than those supplied occurred quickly, and the decrease in the $\mathrm{C}^{\mathbf{1 4}}$ of the amino acids after 1.5 hours was probably because of their respiratory oxidation to carbon dioxide. Although the increase in radioactivity of proline might have resulted from the conversion of the labeled glutamic acid contaminant to proline, it seems likely that proline arose in part from hydroxyproline. The decrease in radioactivity in hydroxyproline was far greater than the increase in radioactivity of proline. During the first 1.5 hours, the $\mathrm{C}^{14}$ in hydroxyproline decreased by over 28,000 c.p.m. while proline accumulated 570 c.p.m. The amino acids recovered account for but a minor part of the total $\mathrm{C}^{14}$ lost from hydroxyproline.
$3.0 \mathrm{hrs}$.

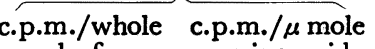
leaf amino acid

11,550

3,150

720

1,290

600

1,650

420

960

57.8

4.4

18.4

4.4

19.0

3.6

-
10 hrs.

$\begin{array}{cc}\begin{array}{c}\text { c.p.m./whole } \\ \text { leaf }\end{array} & \begin{array}{c}\text { c.p.m. } / \mu \text { mole } \\ \text { amino acid }\end{array} \\ 13,800 & - \\ 840 & 12.7 \\ 360 & 2.3 \\ 3,450 & 33.5 \\ 570 & 5.5 \\ 1,860 & 25.4 \\ - & - \\ 720 & -\end{array}$

The amount of aspartic acid in the tobacco leaves increased with time; however, the original content of aspartic acid may have varied somewhat among individual leaves. Aspartic acid and malic acid are the prominent early products of $\mathrm{C}^{14} \mathrm{O}_{2}$ fixation in the dark, and it can be assumed that in our experiment the radioactivity which was incorporated initially into aspartic acid might later have been transferred to other compounds.

The amount of hydroxyproline is generally small compared to the amount of proline in higher plants, but hydroxyproline may be the more active metabolite. Proline may serve chiefly as an end product in amino acid metabolism in the tobacco leaf, whereas our data on the rapid loss of $\mathbf{C}^{\mathbf{1 4}}$-hydroxyproline from the leaves suggests that this amino acid fills an active metabolic role.

Acknowledgement The author expresses his thanks to Professor R. H. Burris and the members in his laboratory for their suggestions and encouragement, and to Dr. I. Uritani and Dr. K. Tomiyama for their kind aid in the experiments. 